New York City has admittedly the largest and most varied immigrant population of the country. It has, however, many competent foreign born physicians who eare for their own kind, besides many hospitals devoted to the care of special foreign groups, like the Italian, French and Lenox Hill (formerly the German Hospitals, besides several others devoted to Yiddish patients. The Health Board of the city is most active and efficient, together .with many other agencies, both public and private, in raising the health standards among the foreign born, and special health lectures are given in different languages in the public schools. The infant mortality of the entire city has never been so low as in the past few years and is a source of amazement to distinguished foreign members of the medical profession who come here. The comments of the author upon the fraudulent medical cults with which the country abounds are well made and nowhere to be better ilustrated than in his own quack-beridden state of California, but it is unfair to shift any of the burden of this upon an assumed negligence of the medical profession, which wages constant warfare against it in its county, state, and national associations, only to be defeated time and again by lay legislators. There are too many other operative factors, notably the sensational press, the general restlessness of the times, and indeed the multiplicity of experimental medical tests themselves, which lead patients to compare experiences with one another and seek all manner of examinations whether they need them or not, in order to get their money's worth out of what the author characterizes as "our commercialized system of private practice"-which remark leads one to wonder whether he knows the average income of the legitimate medical practitioner.

142 E. 62ND ST.,

NEW YORK CITY

NOTE ON INHERITANCE IN SWINE

The Berkshire pig is distinguished by the following characters: (1) erect ears, (2) uniform black coat with the exception of "six white points" which occur on the head, on each foot and on the tail, (3) a short "dished" nose, and (4) a somewhat short and broad body. The Large Black pig is distinguished by (1) "flop" ears, (2) uniform black coat without any white, (3) nose not "dished" and of moderate length, and (4) a long body, somewhat narrower than that of the Berkshire. On a farm near Oxford, pure-bred Large Black boars have for some years been crossed with pure-bred Berkshire sows. About a dozen litters have come under the observation of the author of this note and the $\mathrm{F}^{\mathrm{I}}$ generation has invariably shown (1) erect ears, (2) uniform black coat without any white, and $(3 \& 4)$ intermediate features as regards nose and shape of body. Latterly, the reciprocal cross has been made (Berkshire boar and Large Black sow) and the $F^{1}$ generation shows (1) erect ears and $(3 \& 4)$ intermediate characters. But as regards (2) there has appeared a gradation from pure black to spotted pigs in which the whole coat is fairly evenly divided into black and white patehes. At present the numbers are small, but it would appear that the gradation is not uniform between the pure black and the spotted condition. There appear to be three classes-pure black, black with the six Berkshire points and spotted. Further it is noticeable that the true spotted pigs have hitherto all been boars, though pure black boars have also appeared.

It may be suggested that erect ear is a simple dominant. The coat color and other features clearly require considerable analysis. It may be that sex linkage is in some way concerned in coloration.

A. M. Carr-Saunders

Department of Comparative Anatomy, OXFORD

\section{ON SUMMARIES OF RECENT ADVANCES IN PHYSICS}

THe National Research Council has recently issued two valuable pamphlets on the Quantum theory (The Quantum Theory, E. P. Adams, 1920, No. 5; Atomic Structure, David L. Webster, Leigh Page, 1921, No. 14). Similar contributions on other live topics have come, from time to time, from the Bureau of Standards. I wish to express my personal appreciation of 
this admirable work and hope that more is in store for us.

We, who are about to be shelved, used to live in this country, peacefully under the constitution and we were quite happy in our simplicity. One day a man by the name of Einstein came along and mixed that constitution up. We were told that it had long been an antiquated document anyway. There were diffculties, but eventually we managed to fit in; for they had left us, at least, with the doctrine of energy. Now, I read that the classical law of the conservation of energy must also go, that at best it is only statistical like the second law of thermodynamies. Truly these young bloods are Balkanizing the whole of physies and our ancient constitution has gone the way of the mark.

BRowN UNIVERSITY

Carl Barus

\section{SCIENTIFIC BOOKS}

Trees of Indiana. By Charles C. Deam, State Forester of Indiana. First revised edition. 317 pages; 137 plates. Publication 13 of the Department of Conservation, State of Indiana. April, 1921.

THE forerunner of the present work, under the same title and by the same author, was issued in 1911. So great was the demand for that book that the edition of 10,000 copies lasted only three years, while a second edition, printed in 1919, was exhausted within five days of publication. The present "first revised edition" is fundamentally a new work, with new illustrations and completely rewritten text.

During the past decade numerous "tree books" have been issued by various state organizations, but it is doubtful if any of these contain more original matter than the present work. Certainly none of them contain more local color. The botanical descriptions are based on Indiana material, and the illustrations are photographed from Indiana specimens, while the distributional peculiarities in Indiana of the various species are treated in gratifying detail. It is in this latter particular, perhaps more than any other, that the book will prove of service to the general botanical public. In the course of his studies of the flora of Indiana, the author, within the last ten years, has traveled more than 27,000 miles, by auto, and has visited every county and traversed practically every township in the state. As a result he is able to present, at first hand, a wealth of detail in regard to local tree distribution, not to mention various other observations which bespeak intimate familiarity with the tree flora of the state. The attention given to the ecological relations of the different species is especially worthy of note, and this feature alone will recommend the work to a wide circle of readers.

George E. Nichols

\section{NOTES ON METEOROLOGY AND CLIMATOLOGY \\ SKY BRIGHTNESS AND DAYLIGHT ILLUMI- NATION}

What is the relation between sky brightness and the electric light load earried by the central lighting plant? How much sky-light will be cut off by a row of buildings on the opposite side of the street These questions and many others may be solved by studies of the brightness of the sky and daylight illumination such as have been earried out by Dr. H. H. Kimball, of the Weather Bureau at Washington. The practical utility of such investigations is attested by the interest shown by illuminating engineers, architects and electrical engineers. A paper, recently appearing in the Monthly Weather Review, ${ }^{1}$ summarizes with considerable detail a report submitted to the Illuminating Engineering Society, of whose committee on sky brightness Dr. Kimball is chairman.

The observational program which has been followed in making the measurements has been to make photometric readings with a SharpMillar photometer at elevations of $2^{\circ}, 15^{\circ}, 30^{\circ}$, $45^{\circ}, 60^{\circ}, 75^{\circ}$ and $90^{\circ}$ above the horizon on vertical circles at azimuth intervals of $45^{\circ}$ beginning with the sun's vertical and proceeding half-way around the horizon. Only half the sky is measured because it is assumed that the

1 Kimball, H. H., and Hand, I. R.: Sky brightnegs and daylight illumination measurements. Sept., 1921, pp. 481-488. 